\title{
Discussion on the Construction and Application of Online Open Course Resources in Local Colleges and Universities
}

\author{
Nie HuiYu ${ }^{1, a}$ \\ ${ }^{1}$ Baicheng Normal College, Media Institute, Baicheng, Jilin \\ abcnhy@sohu.com
}

Keywords: Online Courses; Sharing Platform; Curriculum Construction

\begin{abstract}
The construction of online open course resources has injected new vitality into the development of educational information. The online open course construction department of local colleges and universities in Jilin Province has just started. The article analyzes the reasons for the lag of local colleges and universities, and puts forward that teachers and school administrators should change Ideas, correct understanding and actively into the network-based teaching model of the major changes.
\end{abstract}

\section{Introduction}

Online open course is the use of Information Technology tools, the use of information technology network learning platform to carry out the traditional classroom teaching time and space constraints of interactive teaching, the difference of teaching, training students to use information technology independent learning, explore a course of learning, online courses The application of teaching methods, means, teaching mode and teaching management system reform, for the educators to achieve personalized learning, social learning, continuing learning, lifelong learning possible, so that the development of higher education information is facing new opportunities and challenges. The online course can enrich the content of college curriculum, change the activities of college curriculum carrier and curriculum implementation, help to improve the teachers' professional knowledge and skills, improve the classroom teaching effect, help to cultivate students' active learning ability, enrich students' learning life, At the same time, the online course puts forward new challenges to the school level teaching thought, the curriculum resource management, the curriculum credit management, the teaching process management and so on, puts forward the higher request to the teachers' thought consciousness, demands the teacher to master the curriculum development technology, the innovation teaching mode, reposition the teacher role.

China Online Open Course was founded in 2003, has gone from the national excellent course stage, the national boutique online open course construction stage, developed to the online open course comprehensive construction and management stage. With the application of streaming media technology, the upgrading of network infrastructure and the development of network technology, the network education video resources has become more and more popular with teachers and students and schools to become the main and mainstream teaching resources in the network environment. A variety of online open course systems such as video open class, boutique resource sharing class, MOOC and SPOC. MOOC platform construction of the survival and development of colleges and universities put forward great challenges. Colleges and universities have excellent campus network environment, college students have a flexible learning time and learning terminal. If the university classroom teaching model is not reform and innovation, can not keep up the pace of development, students can not be attracted to the classroom, the students will choose to learn other network quality education resources, which the local colleges and universities of the development and reform put forward higher request.

\section{The Current Situation of Online Open Course Resources Development}

April 2015 Ministry of Education in the "on the strengthening of colleges and universities open 
online curriculum construction and management of the views" proposed to build Chinese characteristics of the online open course system and curriculum platform, and strive to 2017 years ago identified more than 1,000 national boutique online open courses, By 2020, the national boutique online open course requirements to reach 3000. Since 2012, MOOCs as a new teaching model, with its unique online courses, knowledge access channels to win the favor of the Internet, and as a turning point for the rapid development of the current international major MOOC base course age, Online university and online courses. Three major platforms to promote the global sharing of resources and curriculum open, to give learners an unprecedented learning experience, and thus become the global network era learners a new choice. 2013 is China's MOOC comprehensive development of the year, many well-known domestic universities have joined the international MOOC platform, while multi-school co-created a number of Chinese MOOC platform. As of December 2016, China's first MOOC platform "love course" website with 111 colleges and vocational schools to carry out cooperation, launched 2948 resources sharing courses. Compared with the national education information construction achievements, the province of local colleges and universities there is a certain gap in the development of information technology teaching. The end of 2015, local institutions of higher learning has been built campus network, but the curriculum resources and platform construction is still far behind the key institutions. "Love course" website Jilin Provincial College online sharing of resources courses 52, in addition to the Northeast Normal University and Jilin University, the other places on the line only 20 colleges and universities.

Table 1: Jilin province undergraduate course colleges and universities "love course" distribution network open courses online profile

\begin{tabular}{|l|l|l|l|}
\hline $\begin{array}{l}\text { Serial } \\
\text { number }\end{array}$ & Colleges and universities & $\begin{array}{l}\text { Online open } \\
\text { courses gate; }\end{array}$ & Subject areas \\
\hline 1 & Jilin University & 28 & $\begin{array}{l}\text { History; Science; } \\
\text { Engineering; Agriculture; } \\
\text { Medicine; Literature }\end{array}$ \\
\hline 2 & Northeast Normal University & 4 & $\begin{array}{l}\text { History; Science; } \\
\text { Engineering }\end{array}$ \\
\hline 3 & $\begin{array}{l}\text { Northeast Electric Power } \\
\text { University }\end{array}$ & 4 & Science; Engineering \\
\hline 4 & $\begin{array}{l}\text { Changchun University of } \\
\text { Science and Technology }\end{array}$ & 4 & Engineering \\
\hline 5 & Jilin Agricultural University & 3 & Science; Agriculture \\
\hline 6 & $\begin{array}{l}\text { Changchun University of } \\
\text { Traditional Chinese Medicine }\end{array}$ & 2 & Medicine \\
\hline 7 & Yanbian University & 2 & Medicine; Literature \\
\hline 8 & North China University & 1 & Agriculture \\
\hline 9 & $\begin{array}{l}\text { Jilin Institute of Physical } \\
\text { Education }\end{array}$ & 1 & Pedagogy \\
\hline 10 & Changchun Normal University & 1 & Pedagogy \\
\hline 11 & Jilin Medical College & 1 & Medicine \\
\hline 12 & Changchun Industrial College & 1 & Engineering \\
\hline
\end{tabular}

By retrieving found that online courses construction in our province are mainly distributed in the field of engineering, science, medicine and other disciplines, and art, economics, law, employment, entrepreneurship class does not courses online. Show open curriculum resources in our province development not balanced, and individual subject areas blank or online courses construction development is slow. In order to speed up the information of the education in our province, to promote higher education quality improve, continuously improve the quality of talent training, the Jilin province medium and long-term education reform and development plan outline of colleges and universities to strengthen the digital campus infrastructure, improve the network learning space, establish higher education resource sharing mechanism, implementing the resources 
sharing of quality development goals. Local undergraduate colleges should seize the opportunity, promote the characteristic discipline and boutique online open course resources construction and sharing platform.

\section{Several Suggestions on Online Open Courses Construction}

\section{A. Increase the Funds Investment, Special Funds to Carry out the Course Construction}

Online courses teaching resources development costs just rely on the school itself is very difficult, the relevant government departments should strengthen the investment of the construction of the course. To establish the subject role of governments at all levels in the education information spending. To encourage businesses investment, and social forces to participate in education information construction and services, formed through various channels to raise funds safeguard mechanism for the education information. Set up special funds for education information, the overall planning, overall management, increase in rural and remote areas education information construction funds subsidies. In various areas, various universities to the information center of invest more in infrastructure construction, strengthen the leading ability in education information construction within their respective jurisdictions. Standards for education information construction and operation maintenance guarantee funds, as a whole to arrange funds, set up a budget system and technical support service system, ensure that the hardware, software, resources, application, operation maintenance, training, such as capital expenditures, constantly promote coordinated development of hardware construction and application.

B. Set up Incentive Mechanism, Improve Teachers' Curriculum Construction.

Online course construction quantity large, specialized and individual teacher is difficult to achieve, to professional education technology, computer network technology personnel and subject teachers work together. After course construction has been verified further to carry out the course construction, the application work ethic, online course application management is a process of accumulated over a long period of time. In order to arouse the enthusiasm of teachers to participate in, and ensure that the course construction, real demonstration leading role play high-quality courses, schools should be set up to the department in charge of teaching as the leading, modern education technology departments, the relevant teaching hospital to participate in the online course construction management committee, set up corresponding incentive mechanism, management system of financial investment and guaranteed. To plan, design, construction, maintenance, promotion, upgrade, exchange and collaboration are taken into consideration, and on the external promotion course application platform of introduction and safety, standard operation and service management.

C. To Carry out the Education Technology Training, to Improve Teachers' Information Technology Application Ability.

Online course video production need professional teachers and education technology staff closely linked, in harmony, requires discipline teachers have certain information literacy, the network video design standards and application requirements have a preliminary understanding, to master the basic way of using the recorded lesson software, therefore need to provide the necessary professional and technical personnel training. Education technology professionals for subject teachers in our school has carried out four times training, training content include online course resources construction standard interpretation; Micro class design and production of basic theory, instructional design theory, etc.; Commonly used teaching editing software applications, such as PowerPoint, Camtasia Studio, figure, mind maps, voice recording editing software, etc. Interdisciplinary professional training, in order to improve the teachers to learn the process online open courses, ensure the technical personnel in the process of curriculum construction and smooth communication between the professional teachers, improve the overall level of curriculum design and manufacture. 


\section{The Innovative Teaching Mode, the Realization of Students' Autonomous Learning.}

Online open courses focus lies in the improvement of students learning effect, so whatever self-built course or an introduction of the teaching quality of the each link to fully reflect the design concept of "taking students as the center". Arrange timely learning test in the video, arrange test and homework after class, and can make learners through system automatically score, autonomous test, a variety of evaluation methods for learning such as peer mutual assessment, effectively guarantee the students' mastery of learning content and learning progress. Encourage teachers to use online open courses to explore flip the classroom teaching methods, the hybrid teaching reform, to carry out inquiry teaching and task driven type, increase student discussion, cultivate students' creative thinking and independent thinking. Completed online learning space, teachers can use online learning space organization, lead and guide the student to study, all the students can use the network learning space to carry out the independent, cooperative and inquiry learning activities, use of network space show the learning outcomes, share the learning resources. Vigorously carry out interactive teaching information environment, differences in teaching, individualized learning, cooperative learning and project learning, promote the innovation and reform of teaching methods, a real change of the traditional classroom teachers in colleges and universities' teaching mode, the establishment of a new information learning mode, cultivate students use information technology to autonomous learning, problem solving, cooperation, innovation practice ability and good habits.

E. Build a Shared Platform, Expand High Quality Resource Yield Surface.

Through information sharing resources to promote the education fair is an important education reform strategy. Establish local colleges can ensure high quality education resources sharing platform in education under the condition of limited resources, improve teaching quality, innovative talent training mode, improve the quality of personnel training, optimize allocation of education resources, resolve the contradiction between the limited education resources and the popularization of higher education, for the profit maximization.

Cooperation can attract and encourage social enterprises and institutions, related educational products manufacturers to participate in sharing platform construction, sharing construction results. Through the enterprise to provide teaching support services, to carry out modern education, the formation of a complete and effective education industry system, so that education resources to maximize the development and utilization, reduce education costs, thereby reducing the economic burden of learners, to avoid duplication of construction and waste of resources, To obtain a huge social benefits.

Connotation to enhance the development of refined high school resources, the development of specific disciplines. Course resources construction can choose to have school-based fine class re-processing, it can be re-built. The construction of the course video should be based on the students' attention and memory rules, the teaching content will be segmented, and the corresponding questions should be set according to the learning content. The course resources should also include the assignments, tests, and so on. Master the situation.

Extension of open development, the joint local institutions and similar colleges and universities to develop education and teaching resources. Local colleges and universities can be with the Northeast Normal University, Jilin University and other key universities or similar institutions of key disciplines jointly developed, cooperative institutions to play their respective academic structure advantages, selected senior experts and scholars held lectures, teachers and admit the amount of teaching, The implementation of the course of mutual selection, credit mutual recognition, unified assessment, decentralized management and other methods, the implementation of teaching resources sharing.

\section{Conclusion}

For colleges and universities, the online open course is not only the innovation of educational technology, it will bring profound changes to the curriculum and teaching of colleges and universities, bring great pressure and challenge to the traditional education and teaching mode. For learners, Real education fair, lifelong education and personalized education; for teachers, they will 
be gradually learned by the knowledge of students to learn the incentive and inspiration. So every educator must be in a positive attitude and willing to change the attitude to accept it.

\section{References}

[1] Liu Shuang. A Study on the Countermeasures of Sharing the Teaching Resources of Quality Education in Colleges and Universities [J]. Information Teaching, 2009 (10);

[2] Qin Libo. Research on the Co-construction and Sharing Model of Information Resources in Application-oriented Universities [J]. Education in China,2015(10);

[3] Zhao Qing. The Influence and Challenge of Online Course on Curriculum and Teaching in Colleges and Universities [D]. Shenyang Normal University,2015(03);

[4] Hu Tiesheng. An Analysis of the Current Situation of the Construction of Micro-course in Colleges and the Countermeasures [J]. Modern Educational Technology, 2014(02);

[5] Sun Zhong.Push Strategy and Technology Realization of Personalized Learning Resources in Digital Textbooks [J]. Research on Education Technology,2014(09);

[6] Zhu Zhiting.Wisdom Education is a New realm of Educational Information [J] .Research on Education Technology, 2012(12). 